\title{
Hard Times for Unions: Challenging Times for Scholars
}

\author{
Paul C. Weiler $\dagger$
}

\section{INTRODUCTION}

It is rather disconcerting to open an envelope from a law review and find enclosed a manuscript of a forthcoming article to which the editors are asking you to respond. In this case, a quick glance at the opening page of Hard Times for Unions ${ }^{1}$ revealed that Professors LaLonde and Meltzer were referring to my article, Promises to Keep," as a "celebrated work." I knew full well, though, that their aim in the next hundred pages was certainly not to praise my work. And as I read LaLonde and Meltzer's thorough investigation of the National Labor Relations Board's unfair labor practice docket, I found myself regularly enlightened by the authors' observations. Indeed, I felt some considerable regret that my book, Governing the Workplace, was already set in print and was destined to appear without any of the revisions I might have wanted to make to my own figures.

Now, though, having carefully reread and reflected on Hard Times for Unions, I realize that I would not have had to change a single significant claim made in Governing the Workplace, which elaborates and somewhat alters the argument made in Promises to Keep. In fact, I am grateful to LaLonde and Meltzer for having undertaken the laborious task of providing an even more durable statistical underpinning for my basic thesis than is to be found in

\footnotetext{
$\dagger$ Professor of Law, Harvard University.

1 Robert J. LaLonde and Bernard D. Meltzer, Hard Times for Unions: Another Look at the Significance of Employer Illegalities, 58 U Chi L Rev 953 (1991).

2 This article, the full title of which is Promises to Keep: Securing Workers' Rights to Self-Organization Under the NLRA, 96 Harv L Rev 1769 (1983), addressed the legal policy issues in the union organizing drive and the election campaign. A companion article, Striking A New Balance: Freedom of Contract and the Prospects for Union Representation, 98 Harv L Rev 351 (1984), focused on the legal framework for negotiation of a first contract by a newly certified union. Then came Milestone or Tombstone: The Wagner Act at Fifty, 23 Harv J Leg 1 (1986), a policy essay in which I drew together the major themes from the earlier in-depth treatments. Finally, my recently published book, Governing the Workplace: The Future of Labor and Employment Law (Harvard, 1990), puts my entire argument in a much broader context.
} 
my comparatively cursory reliance on NLRB data. Indeed, after reading their article I was left with the feeling that the authors simply did not get the true point of the patterns and trends they had uncovered.

\section{WeILeR's Thesis: Part ONe}

The thrust of my own writing in this area has been to develop the case for searching legal reforms that would better protect employees from firings and other reprisals when they exercise their half-century-old statutory right to a collective voice in the workplace. That argument consists of three components. The first is empirical evidence showing that growing employer opposition to union representation plays a major (though by no means the sole) role in the decline of unionism. ${ }^{3}$ The second is an extended explication of why such an organized employee voice is valuable, and why employer resistance is therefore a social evil worth tackling. ${ }^{4}$ The third is a strategic policy analysis of which legal and institutional innovations could make a tangible contribution to attaining that objective. ${ }^{5}$ LaLonde and Meltzer's article is directed at one aspect of the empirical component in my argument. To better explain why I believe their article actually buttresses my case, I shall briefly synopsize the policy context within which these data are offered. $^{6}$

The one point about which there is absolutely no doubt is that these are hard times for unions, particularly in the private sector

${ }^{3}$ My analysis of the extent and significance of this phenomenon was first developed in Promises to Keep, 96 Harv L Rev at 1771-86 (cited in note 2), then updated and elaborated in Striking A New Balance, $98 \mathrm{Harv} \mathrm{L}$ Rev at 353-57 (cited in note 2); in Milestone or Tombstone, 23 Harv J Leg at 3-12 (cited in note 2), and most recently in Governing the Workplace at 105-18, 233-41 (cited in note 2). Extensive documentation and references for my empirical claims are contained in those publications. At the suggestion of the editors, in this reply article I shall simply give the citations to the relevant pages in my own work where the interested reader can find support for the assertions made here.

- A major theme of Governing the Workplace, in particular chapters 3 and 4, is that some form of union representation and free collective bargaining are essential components of a well-functioning market economy and political democracy. At the same time, chapter 5 of Governing the Workplace develops a critique of the manner in which the standard American version of this form of worker representation has served these economic and political values.

- Chapter 6 of Governing the Workplace contains a systematic restatement of my current views of how we should reform the NLRA and why reform must transcend the confines of labor law.

( Though LaLonde and Meltzer deal with a host of empirical issues, to keep this response to a manageable length I confine myself to the point we all consider to be the most significant: the extent of and trends in employer firings of union supporters during the representation contest. 
of the economy that is under the purview of the National Labor Relations Act (NLRA). Approximately 15 percent of the private sector workforce was represented by unions in the early ' 30 s, just before passage of the Wagner Act. In the more favorable legal and political climate that prevailed after the passage of the Wagner Act, union representation soared to a peak of approximately 40 percent of the workforce by the mid-'50s. ${ }^{7}$ Then began the steep decline to today's figure of well under 15 percent-a figure that is projected to fall below 10 percent by the turn of the century. ${ }^{8}$

LaLonde and Meltzer acknowledge that there is no satisfactory structural explanation for this union slide. ${ }^{9}$ It is true that in the mid-'50s, male blue collar production workers in the northern states formed the core of the union movement, while the major expansion in the workforce since that time has been among female white collar service workers in the south. However, the conjunction of these two facts simply begs the question of why American unions were not able to put down roots in these faster-growing sectors of employment, in the same way that the union movement had proved itself capable in the ' 30 s of shifting its center of gravity from its original craft stronghold to the mass production industries. In any event, this proposed demographic account does not square with the fact that since the ' 50 s, unions have also lost major ground within their manufacturing and construction bases while simultaneously achieving major breakthroughs in the public sector, in such quintessentially "female" service occupations as teaching, nursing, and government clerical work. ${ }^{10}$

It is true that the union movement is subject to a constant process of natural attrition in its "market share," as already-organized facilities close, relocate, or shrink in size. Just to stay even, then, unions must continually establish their presence in new units at previously unorganized locations. That process faces two legal and practical hurdles. First, a union must petition for and win an NLRB election, and then the newly certified union must negotiate the first collective agreement that actually puts its imprint on wages and working conditions. The aggregate decline of unions in the private sector is mirrored by statistical trends in these indivi-

\footnotetext{
7 See Promises to Keep, 96 Harv L Rev at 1771-72 (cited in note 2); Governing the Workplace at 8-10 (cited in note 2).

- See Governing the Workplace at 10 (cited in note 2).

- See LaLonde and Meltzer, $58 \mathrm{U}$ Chi L Rev at 958 (cited in note 1).

${ }^{10}$ See Promises to Keep, 96 Harv L Rev at 1773-74 n 6 (cited in note 2); Governing the Workplace at 107-08 (cited in note 2).
} 
dual representation contests. Whereas in the mid-'50s unions won elections covering nearly 75 percent of the eligible workforce, by the '80s that victory percentage had been cut in half, to under 40 percent.." Similarly, in the '50s unions were able to translate their certifications into first contracts nearly 90 percent of the time. By the early ' $80 \mathrm{~s}$, however, unions secured such agreements from previously nonunion employers only 50 percent of the time. ${ }^{12}$ Together these two hurdles leave unions with a bottom-line yield from their current organizing efforts at between 20 and 25 percent, only a third of what it was 30 years ago.

While these NLRB statistics present a graphic picture of precisely how unions have been declining, they leave open the question of why this has been happening. The simplest explanation is that unionism has lost much of its appeal. The popular impression is that unions are large, bureaucratic organizations, led by remote leaders who are unrepresentative of, and out of touch with, the new breed of American workers. Polling data indicate that unions have fallen considerably in public favor, ${ }^{13}$ though it is doubtful how much of this sentiment reflects actual membership dissatisfaction with its own union's performance. ${ }^{14}$ Still, if the cause of union decline is rejection by American workers of the institution, there is nothing that the law can or should do about that verdict. ${ }^{10}$

Although a decline in union appeal is certainly a part of the story, it is not the entire story. For example, the impression conveyed by popular opinion polls does not account for the surge of

1 See Promises to Keep, 96 Harv L Rev at 1776, Table 1 (cited in note 2). The numbers reported by LaLonde and Meltzer, a 68 percent union victory rate in certification elections during 1950-59 and a 43 percent rate during 1980-88, $58 \mathrm{U}$ Chi L Rev at 961, Table 2 (cited in note 1), considerably understate the true decline experienced by unions. Unions now tend to win elections in smaller employee units and to lose in the bigger units-the ones in which the employer deploys greater resources to fight the representation effort.

${ }_{12}$ See Striking A New Balance, $98 \mathrm{Harv} \mathrm{L}$ Rev at 354-55 (cited in note 2). Although unions secure first agreements in more than 60 percent of all newly certified units, their success rate is considerably less when they must deal with employers who do not already have a union contract in their operations-a contract that would naturally be applied to a newly organized facility.

${ }_{13}$ That is true, at least, if one compares the overall trend in Gallup opinion polls since the mid-'50s. One should note, though, that the net public approval rate for unions actually shot up in the ' 80 s at the same time as union density was experiencing an especially severe decline. See Governing the Workplace at 106-07, 298-99 (cited in note 2).

14 See Governing the Workplace at $277 \mathrm{n} 65$ (cited in note 2). Indeed, a 1988 Gallup Poll demonstrated strong public support for the key functions performed by unions in the workplace. See id at 108-09, 298-300.

${ }^{15}$ However, my conclusion in id at $282-306$, is that the polity does have a responsibility to prescribe a basic form of indigenous employee representation in a firm's plants and offices as an alternative to or a floor for full-blown collective bargaining. 
union activity among government employees, who are members of that same general public. ${ }^{16}$ Even within the private sector there is a puzzle in the statistics encapsulized above. Before a union can start the NLRB process in motion, it must establish a "showing of interest" among the particular group of employees, consisting of written allegiance. from a legal minimum of 30 percent (but in practice from well over 50 percent) of the unit. It is among these already organized groups of employees that unions are now winning elections covering less than 40 percent of those eligible and, even after winning elections, securing contracts covering only three of five such units. It is easy to understand why, if the yield from these initial organizing efforts has dropped so sharply, unions (and currently unorganized workers) will be much less willing to make the effort in the first place. The puzzle is why, once a union has successfully surpassed the first hurdle-the expression of interest among employees-it is unable just a few weeks or months later to translate that interest into certification and a collective agreement.

A major part of the answer to this question can be found on the other side of the table, in resistance from employers. The phenomenon of stubborn employer opposition to unionism-aided by management consultants-both before and after the election is readily visible to those who practice in this sector. Of course, such resistance can take the form of either legal or illegal measures. Even if the measures are legal, they are not necessarily legitimate or desirable. For example, an employer that does not want to deal with a union can simply close the recently unionized plant or liquidate its operations. Alternatively, the employer can bargain the union to a standstill, force the employees to strike in order to get an improvement in their compensation or employment conditions, and then permanently replace the strikers with new recruits antipathetic to the whole effort. Equally important, in the hotly contested campaigns that precede NLRB elections, a carefully briefed management can tell employees that such a fate is precisely what is in store if they vote for the union.

Yet for better or worse, labor law proclaims these employer tactics to be legal forms of resistance (at least if done carefully with a lawyer's advice). My work has focused on an action that clearly is illegal: the firing of union supporters during the election

\footnotetext{
${ }^{16}$ Approximately 40 percent of public sector employees are represented by unions, see Promises to Keep, 96 Harv L Rev at 1771-72 n 4 (cited in note 2), and considerably more than this number are represented by unions in the states that give public employees a right to such representation if they want it.
} 
campaign or the negotiation of the first agreement. Although in the ' 30 s the then-new $\S 8(a)(3)$ of the NLRA-the discriminatory discharge provision-was hotly contested by employers in both the political and constitutional arenas, by the mid-'50s its legitimacy seemed generally accepted in this country. At least the rate of discriminatory discharges upheld by the NLRB had dipped to around 1,000 a year at the same time that union representation had peaked at around 40 percent. ${ }^{17}$ Then the level of illegal firings began spiralling, far exceeding the coincident decline in union election success. Charges of $\S 8(a)(3)$ violations by employers soared from 3,000 in 1955 to over 18,000 by 1980 (and from 4,000 annually in the late ' 50 s to 16,000 in the early ' 80 s). Of course, these are the figures for charges, not for proven violations of the Act. A much better index, then, is the rate of actual reinstatements secured by the NLRB following the filing of such charges by employees or unions. From the 1955 rate of roughly 1,000 reinstatements, this figure had jumped tenfold by 1980 to more than $10,000 .^{18}$

Some, including LaLonde and Meltzer, have suggested that these absolute numbers of firings are deceptive, because they do not control for greater levels of employee exposure due, for example, to the fact that the overall workforce has grown steadily and that the NLRB's jurisdiction over that workforce has been expanded by a number of factors. ${ }^{19}$ of course, such bare potential exposure is irrelevant by itself: the real questions are how many NLRB election campaigns are actually held each year in which an employer might be tempted to make an illegal discharge, and how many union supporters are involved in these elections and exposed to such reprisals. The answer is that the number of certification elections in the ' 80 s is approximately the same as it was in the '50s and the number of union voters is far lower. ${ }^{20}$ Putting these statistics together with the NLRB reinstatement figures noted above suggested to me that a discriminatory discharge took place in one election in three ${ }^{21}$ and that one worker was illegally fired for every

17 For these and the other figures cited in this paragraph, see Promises to Keep, 96 Harv L Rev at 1779-81 (cited in note 2); Governing the Workplace at 237-40 (cited in note 2).

${ }_{18}$ When I went back to look at Board statistics for 1985 while writing Governing The Workplace, the reinstatee rate was still over 10,000 in that year. But as LaLonde and Meltzer's Table 3 indicates, $58 \mathrm{U}$ Chi L Rev at 962 (cited in note 1), the average in the early to mid-'80s was roughly 7,000 reinstatees annually.

$1958 \mathrm{U}$ Chi $\mathrm{L}$ Rev at 969-70 (cited in note 1 ).

${ }^{20}$ See Promises to Keep, 96 Harv L Rev at 1776, Table 1 (cited in note 2); Governing the Workplace at $277 \mathrm{n} 64$ (cited in note 2).

21 This ratio, which was calculated from data provided to me several years ago, was first 
twenty union voters. These numbers seemed to be telling evidence of the presence and likely impact of employer resistance to union representation among American workers.

\section{My Reactions to the LaLonde and Meltzer Challenge}

The foregoing presents the first half of my empirical argument for labor law reform. Although it is not the most important half (that will come later), it does bring us to the key point at which LaLonde and Meltzer take issue with my factual assertions. They claim that by counting all reinstatements as though they occurred in the context of a representation contest, I substantially overestimated the union supporters' actual risk of dismissal. ${ }^{22}$ Thus, instead of my projection for the early ' 80 s- that one in three election campaigns involved an illegal firing inflicted on one victim for every twenty union voters-LaLonde and Meltzer's close analysis of the actual context of each one of their sample of $\S 8(a)(3)$ adjudications leads them to state that the true odds during the period in question were one firing per five elections, victimizing one out of sixty-three union voters. ${ }^{23}$ Interestingly, they place the current risk at one firing in every three elections, and one discharged employee for every thirty-six union voters.

Obviously $\S 8(a)(3)$ has a considerably broader scope than the union organizing drive. Indeed, until the Reagan Board called a halt, ${ }^{24}$ considerable use was being made of this provision by nonunion workers. That is why at every point in my writings at which I juxtapose the number of union voters and the number of NLRB reinstatees, I have been careful to add the same caveat as do LaLonde and Meltzer against making a precise comparison of these two numbers. ${ }^{25}$ In my first article dealing with the issue, Promises

reported in Milestone or Tombstone, 23 Harv J Leg at $11 \mathrm{n} 17$ (cited in note 2), and then

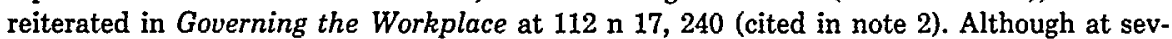
eral points in their article, LaLonde and Meltzer impute to me a ratio of disciminatory firings to certification elections that is far higher than this, see $58 \mathrm{U}$ Chi L Rev at 994, Table 7 (cited in note 1 ), I have consistently asserted that only a minority (albeit a sizable minority) of employers flout the labor laws in this fashion.

${ }^{22} 58 \mathrm{U}$ Chi L Rev at 966 (cited in note 1 ).

${ }^{23}$ Id at 990-92.

24 See Meyers Industries, Inc., 268 NLRB 493 (1984).

${ }^{25}$ See Promises to Keep, 96 Harv L Rev at 1781 and n 35 (cited in note 2); Striking $A$ New Balance, 98 Harv L Rev at $356 \mathrm{n} 13$ (cited in note 2); Milestone or Tombstone, 23

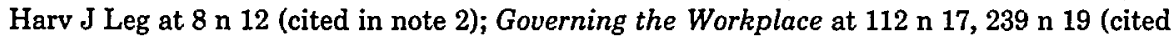
in note 2). Although I have always acknowledged and tried to estimate the extent of the overcount attributable to this factor, I have also pointed out the likelihood that there is at least some offset from the undercount that is inevitable in official records of real life legal 
to Keep, I drew upon the NLRB's study of its own caseload in the late ' 70 s in order to permit me to estimate the degree of overcounting involved. This study found that approximately 90 percent of $\S$ 8(a)(3) complaints related to representation campaigns. ${ }^{26}$ Because, as LaLonde and Meltzer point out, that study analyzed the NLRB caseload just prior to the big leap in reinstatee numbers, ${ }^{27}$ in my later writings (prior to Hard Times for Unions) I relied on a subsequent GAO analysis of such complaints in the early ' 80 s. The GAO study suggested that 60 percent was closer to the true proportion $^{28}$ - not far from the 50 percent share calculated by LaLonde and Meltzer. ${ }^{29}$

LaLonde and Meltzer do add a persuasive refinement to this analysis, one I wish I had thought of myself. They observe that for any given $\S 8(a)(3)$ complaint, the number of employees involved and reinstatements ordered is likely to be considerably higher in disputes occurring within established collective bargaining relationships than in complaints arising out of the initial representation context. ${ }^{30}$ Failing to adjust for this factor does materially overcount the total number of fired employees-though not the affected campaigns-in the latter context.

There are, however, at least two countervailing adjustments that LaLonde and Meltzer do not make, although they should have. One of these adjustments is modest; the other is likely major. These two omissions leave their estimates as something of an undercount.

As I read what they have done, LaLonde and Meltzer do not include in their ratio the discriminatory firings that occur during the negotiation of the first agreement. Although firing a union supporter after an election obviously cannot influence the way an employee would have voted in that election, these firings do have a significantly depressing effect on the likelihood that the union will be able to win a first contract-which is, after all, the point of the election. ${ }^{31}$ Even more important, the prospect that a union sup-

violations. As discussed below, LaLonde and Meltzer simply ignore the latter factor, though I explicitly pointed it out whenever I have explored both sides of the problem with the bare NLRB statistics.

${ }^{26}$ See Promises to Keep, 96 Harv L Rev at 1781 n 35 (cited in note 2).

${ }^{27} 58 \mathrm{U}$ Chi L Rev at 969 (cited in note 1).

${ }^{28}$ See Striking A New Balance, 98 Harv L Rev at $356 \mathrm{n} 13$ (cited in note 2); Governing the Workplace at $239 \mathrm{n} 19$ (cited in note 2).

${ }^{28} 58 \mathrm{U}$ Chi L Rev at $987-88$ (cited in note 1).

${ }^{30}$ Id at 986, 992.

${ }^{32}$ See Striking A New Balance, 98 Harv L Rev at $357 \mathrm{n} 15$ (cited in note 2); Milestone or Tombstone, 23 Harv $\mathrm{J}$ Leg at $10 \mathrm{n} 15$ (cited in note 2). 
porter could be fired at any stage in the representation contest, of which the election campaign and the first contract negotiations are vital and closely related components, is likely to have a significant deterrent influence on whether other groups of employees undertake the risky organizational effort in the first place. That is why the proposed Labor Reform Act of 1977 (together with the NLRB's study of the Act's potential effect on the Board's workload) singled out for special remedial action discriminatory discharges of union supporters during both phases of this single contest.

LaLonde and Meltzer's truncated picture of the representation contest is thus not supportable in principle. Their numbers suggest, however, that adding the first contract context would make only a modest tangible difference in practice. A much more important omission is due to their assumption that the only illegal firings that actually occur during representation contests are those brought to the attention and proved to the satisfaction of the Board, and which eventually produce a reinstatement offer for the fired employees. By contrast, I have not been too uncomfortable about the admitted overcount of representation-based firings in the Board's aggregate reinstatee statistics, because I believe these statistics represent a considerable undercount of the total number of illegal firings actually taking place.

Certainly everything I know about the litigation process implies that positive official verdicts considerably understate the true dimensions of a lawbreaking phenomenon in the real world..$^{32} \mathrm{We}$ must assume then that at least a few employees who are illegally dismissed during a representation contest do not identify themselves as victims of anti-union discrimination; others prefer not to make an issue of their dismissal and do not file a charge as a result of it. Of those who do file charges, a considerable number are not

32 That fact was brought vividly home to me by the results of a major empirical study of medical injuries and malpractice litigation in New York for which I was one of the principal investigators. This study found a large gap between negligent injuries inflicted in the hospital and tort claims being made and paid in the tort system, even in New York, a state that has among the highest rates of malpractice claims and insurance premiums in the country. See Harvard Medical Practice Study, Patients, Doctors, and Lawyers: Medical Injury, Malpractice Litigation, and Patient Compensation in New York ch 7 (Harvard, 1990). A number of other sources drawn on by the American Law Institute's recent report on the tort system (for which I served as Chief Reporter), 1 Enterprise Responsibility for Personal Injury ch 1 (ALI, 1991), show that similar gaps exist between other kinds of personal injuries and the initiation (let alone the successful pursuit) of a tort claim. Although I believe that an administrative board such as the NLRB is considerably more accessible than is the civil justice system, I am still convinced that there are significantly more employees illegally fired by employers than ultimately secure reinstatement from the Board. 
able to prove their case; and even among those who have a valid case, some workers prefer to accept a monetary payment rather than hold out for reinstatement in a job to which they would now rather not return. Even granting that NLRB procedures are sufficiently accessible and inviting that they screen out far fewer meritorious claims than do other parts of the legal system, there is still ample scope for this filtering factor to make up for much of the overcount in fired union supporters that LaLonde and Meltzer and I attribute to the contextual factor.

LaLonde and Meltzer ignore the possibility that NLRB statistics are as likely to understate as to overstate what employers are doing in the real world, in part because they believe that the spiralling rates of unfair labor practice charges against employers simply reflect the increased litigiousness of employees. As corroboration, they observe that unfair labor practice charges against unions jumped dramatically from 1950 to 1988 without evoking a comparable outcry about spiralling union lawlessness. ${ }^{33}$

LaLonde and Meltzer's comparison, however, leaves out important facts. In 1950 the legal exposure of unions under the NLRA was in its infancy, with a host of statutory and doctrinal expansions yet to take place. By contrast, the basic content of the employer's \& 8(a)(3) obligations in the representation contest was clearly established by the mid-' 50 s, with the only significant doctrinal change since that time making discriminatory discharges somewhat harder to prove. ${ }^{34}$ Furthermore, not only did the absolute number of $\S 8(\mathrm{a})(3)$ charges increase six-fold from 1955 to 1980 , but the proportion of meritorious charges against employers doubled within the much higher absolute number in the later year. ${ }^{35}$ One cannot dismiss the recorded leap from 1,000 to 10,000 actual NLRB reinstatees as evidencing nothing more than a greater employee propensity to sue.

\section{A Political Fable}

This debate about the true number of union supporters who are illegally fired has focused on the denominator side of the ratio: How many of the employees reinstated by the NLRB were actually fired during the representation contest rather than as the outcome of a dispute within an established bargaining relationship? No

${ }^{33} 58 \mathrm{U}$ Chi L Rev at 1001-02 (cited in note 1).

${ }^{3 *}$ See NLRB $v$ Transportation Management Corp., 462 US 393 (1983).

3s See Promises to Keep, 96 Harv L Rev at 1780 n 34 (cited in note 2). 
mention has yet been made of the numerator side of the equation: Who is a union supporter? And should one rely on the numbers of pro-union voters for that purpose? Even though a union voter certainly supports the union in the crucial election step of the procedure, casting a secret ballot for collective bargaining does not make an employee a target for employer reprisals to anywhere near the extent that espousing the union's cause does.

But having noted the vulnerability of yet another unduly restrictive assumption in LaLonde and Meltzer's calculations, it is time to declare an end to this statistical debate and to invite the reader to reflect on what difference this all makes. Assume for the sake of argument the validity of LaLonde and Meltzer's numbers: one in three NLRB elections now involves an illegal firing, thereby victimizing one employee for every thirty-six who vote for unions in these elections. On this foundation, somewhat closer to statistical bedrock, I am perfectly prepared to rest my case for major surgery on the NLRA. Why aren't Professors LaLonde and Meltzer similarly concerned?

To underscore why I find our debate so curious, I borrow an analogy from the political arena. Imagine a group of countries in Central America with traditional authoritarian regimes. Under pressures from a variety of sources, these countries periodically conduct referenda about whether their citizens will be given a guaranteed voice in national affairs and, if so, who is to be their representative in dealing with the authorities. Naturally unhappy about this threat to their own prerogatives, the rulers are wont to campaign vigorously against such a major step by the polity. The unhappy result, as documented and recorded by an outside body that monitors such elections, is regular abuse of power by officials meting out reprisals against supporters of a new democratic order.

After some experience with the referendum process and disappointment that more and more of the popular verdicts are cast for the authoritarian status quo, a scholar comes in to look at the reports of the monitoring agency, pulls the available figures together in a rough and ready fashion, and discloses that retaliatory actions appear to be taking place at one in three polling stations, victimizing one citizen for every twenty who votes for democratic change. I suspect that publication of these figures would quickly become "celebrated" indeed and would be read as a powerful case for reforming the entire referendum process.

However, once the debate over which reforms were likely to prove effective and acceptable was underway, a decade or so later another pair of scholars takes a second, more meticulous look at 
the underlying data to identify precisely which reprisals and which victims were part of the election process itself. They publish their new scholarly conclusion that although one in every three polling stations is indeed the site of such reprisals, only one of every thirty-six voters for political democracy is now the target of such action. Though the second article deplores in passing the occurrence of such coercive reprisals, its only policy proposal is a call for better classification and identification of the electoral data. Apparently, the main concern is that future scholars will not be misled as was the unfortunate trailblazer.

That tale, in a nutshell, captures my reading of LaLonde and Meltzer's Hard Times for Unions. Unsurprisingly, I draw a far different conclusion from the article's laboriously gathered statistical data.

\section{WeILeR's Thesis: Part Two}

The fallacy in the underlying logic of Hard Times for Unions is that absolutely nothing in the case for labor law reform turns on the precise accuracy of the one-in-twenty discharge ratio, however eye-catching that figure might be. Suppose, for example, that the true ratio was that only one in every one hundred open union supporters was fired. Would that pattern of behavior constitute a problem? By analogy, my empirical research in the medical malpractice area discloses that one in one hundred hospitalized patients is the victim of a negligently inflicted medical injury - that is, a "tort"-and that one in three hundred patients suffers a moderately disabling injury or worse. ${ }^{36}$ The uniform reaction of audiences to whom I relate these injury risks is that they disclose a very serious problem of quality assurance in medical treatment, requiring a searching second look at our medical liability system. ${ }^{37}$ Shouldn't precisely the same reaction be appropriate for LaLonde and Meltzer's report that one in three employers involved in a representation contest is prepared to fire one in thirty-six union voters (and presumably a considerably higher proportion of open union advocates) among their workforces?

Indeed, another feature of the union election firing magnifies the significance of these dismissal risk ratios far beyond their actual incidence. Unlike the negligent doctor, the aim of the law-

\footnotetext{
36 See Harvard Medical Practice Study at ch 6 (cited in note 32).

${ }^{37}$ A look I have just undertaken in Paul Weiler, Medical Malpractice on Trial (Harvard, 1991).
} 
breaking employer is not just to get rid of the particular employee who has proved himself disloyal by advocating a union, but also to send a message to other employees not to follow the same course. Equally important, the fact that one employer in three is prepared to flout the NLRA in that fashion evokes great uneasiness about undertaking a union campaign even in the minds of employees of good employers-employers who are willing to paint a bleak picture of the unhappy consequences of their employees' embracing unionism, but who are loathe to go so far as to fire union supporters in violation of a half-century-old ban on such action.

The importance of this second-order effect is vividly displayed in national surveys that ask current non-union employees about what they thought was happening in representation contests. The dismaying fact is that approximately 70 percent of non-union American workers believe that some employers fire or otherwise mistreat employees who campaign for a union, and 40 percent report that their own employers would take that action against them. ${ }^{38}$ That level of employee apprehension is only slightly more pessimistic than the true odds of one in three employer campaigns as LaLonde and Meltzer and I detected. Surely this crucial psychological impact indicates the insignificance of our statistical debate over whether the number of employees illegally fired every year amounts to 5 percent or 3 percent of union voters.

One reason this employee concern is now so widespread is that the risk of employer retaliation has increased so much. That fact fairly leaps from LaLonde and Meltzer's Table 7, in particular Panel $\mathrm{A}$, in which the authors depict their own more "modest" estimates of recent trends. ${ }^{39}$ Because of data limitations, this Table tells the story only from the late ' 60 s, roughly a decade after the rise in employer unfair labor practices actually began. At the LaLonde and Meltzer starting point, the estimated risk of illegal discharge was one per twelve elections and one per two hundred or so union voters. By the late ' 80 s, the risk was one per three elections and one per thirty-six union voters. Depending on the measure used, then, in just two decades a fourfold or a sixfold leap occurred in the rate of employer reprisals against union supporters.

\footnotetext{
3s See Governing the Workplace at 117 n 25, 300 n 91 (cited in note 2). Nearly 40 percent of currently nonunion, nonmanagerial employees said that they would not join a union because of company pressure. See Milestone or Tombstone, 23 Harv J Leg at $11 \mathrm{n} 18$ (cited in note 2).

39 $58 \mathrm{U}$ Chi L Rev at 994 (cited in note 1).
} 
On their face these numbers seem to state a rather compelling case for labor law reform. An immediate and sufficient reason is simply to give more effective protection to the thousands of workers being fired for exercising their legal rights. An additional and important reason is to safeguard the union representation process from the chilling effects of such reprisals. As to the latter ground, the simple conjunction of the two statistical trends-the steep rise in employer firing and the sharp decline in union victories-makes a strong intuitive case for a causal connection between the two. LaLonde and Meltzer attempt in a variety of ways to downplay any such connection, though to my mind their choice of statistical measures and timeframes severely impairs that effort. But such professorial tinkering with bare numbers in law reviews is really beside that point. As I have made clear in all my writing on this topic, the acid test for any such causal connection has to be a systematic econometric analysis of variations in outcomes across geography and time, controlling for other factors. The reason I was originally persuaded that the rise in employer unfair labor practices had a real impact on the decline in union victories is that I had the good fortune of being introduced to sophisticated work by my social science colleagues in Cambridge and elsewhere that demonstrated precisely that fact. ${ }^{40}$

Those positive findings are especially significant because both the statistical record and the social science analyses of what has happened in the past tend to understate the impact of a phenomenon that also materially influences the incentives and behavior of actors for the future. ${ }^{41}$ For example, as some anti-union employers show that unions can be beaten by use of fair means or foul, their success tempts other employers to emulate these tactics. Increasing pressure is now felt by managers to preserve, even to restore, a union-free environment in their operations. And the majority of employers who do choose to comply with the NLRA, a statute that leaves them ample room to legally tap latent employee fears, get a free ride on the spillover effects of the crude retaliatory measures utilized by the "rogue employers" (to use LaLonde and Meltzer's epithet). ${ }^{42}$

\footnotetext{
10 See the various studies cited and synopsized in Promises to Keep, $96 \mathrm{Harv} \mathrm{L}$ Rev at 1784-86 (cited in note 2); Striking a New Balance, 98 Harv L Rev at 356-57 nn 14-15 (cited in note 2); Milestone or Tombstone, 23 Harv J Leg at 9-10 (cited in note 2); Governing the Workplace at 112-14 (cited in note 2).

11 The next three paragraphs summarize an argument made at greater length with supporting references in Governing the Workplace at 114-18, 275-81 (cited in note 2).

42 Sixty percent of nonunion workers told a 1988 Gallup Poll that a representation campaign would produce great trouble and tension in their workplace, see Governing the Work-
} 
The other side of the coin is that as employer prospects improve, the union's odds correspondingly decline. I noted earlier the sharp drop in union yield in translating even initial organizing success into election victories and negotiated contracts. Not surprisingly, then, union leaders feel considerable reluctance to invest their current members' scarce dues dollars on what must often seem a futile quest to spread the benefits of union representation to the currently unorganized workforce. ${ }^{43}$ That understandable union reaction shows up in the LaLonde and Meltzer tables depicting a sharp recent drop in the number of NLRB elections that are held in the first place.

Most important of all are the reactions of employees. It is very easy for an employee to become and remain non-union. All he needs to do is go to work in one of the vast majority of plants and offices-including all newly opened worksites-in which management provides its employees the "natural" status of no union. However, if employees want to secure any organized voice in the affairs of their workplace, they must assume the arduous task of persuading à substantial majority of their fellow workers to join in a certification petition to the NLRB, vote for a union in an election, and then insist on a collective agreement from their hardbargaining employer. Even in an entirely risk-free atmosphere, it takes a considerable degree of commitment by the employee to his job and to the union cause for such an effort to appear worthwhile. But as LaLonde and Meltzer have graphically demonstrated, that effort is anything but riskless. The clear message that employees get from what is happening in NLRB elections ${ }^{44}$ is that if they are planning on a career with a particular firm and its management, they should think twice before openly espousing their supposed legally guaranteed right to union representation and collective bargaining.

\section{My Challenge to Professor Meltzer}

Placed in proper context, then, LaLonde and Meltzer's careful digging through NLRB data corroborates rather than undermines

place at $117 \mathrm{n} 25$ (cited in note 2), thus making the entire exercise a rather uninviting prospect.

13 As if to reinforce that inclination of union leadership, the Court held in Ellis $v$ Brotherhood of Railway Clerks, 466 US 435 (1984)-arguably one of the Court's most preposterous labor law decisions-that a union had no positive right to expend dues monies collected under a privately negotiated agency shop contract for purposes of organizing new workers, on the judicial assumption that such outside organizing efforts were not signifcantly related to the interests of already represented employees.

is Recall the polling data referred to in notes 38 and 42 . 
my earlier judgment that the rise of employer reprisals-particularly discriminatory discharges-against union supporters is one of the important reasons why private sector union representation has declined so sharply over the last three decades. Indeed, as I stated at the outset of this reply, I am surprised that the authors themselves have not recognized the implications of their own findings.

My sense of bemusement at this gap in Hard Times for Unions leads me to direct this challenge to Professor Meltzer in particular. Bernard Meltzer is one of the giants of labor law scholarship. His extensive writings over the last four decades have justly earned him the encomium of "our finest craftsman,"45 and his mastery of NLRB doctrine and procedure is displayed on page after page of Hard Times for Unions.

However, in Promises to Keep, my first article about United States labor law, ${ }^{46} \mathrm{I}$ lamented the fact that this elaborate body of labor law jurisprudence and scholarship was serving as "an elegant tombstone for a dying institution." So far as I know, Hard Times for Unions is the first article by Professor Meltzer to address the crucial question of what, if anything, labor law should do to foster and protect the very existence of union representation for American workers. Here I find a strange undertone in the article. Although the authors occasionally comment that discriminatory discharges are sharply increasing and are at a rather high level, they immediately add the caveat that things are not as bad as Weiler said. Apparently, then, we needn't worry or do anything about the problem except change the Board's statistical formats so that future Weilers won't be similarly misled.

Whatever the impression created by the text of Hard Times for Unions, I am sure that this undertone does not accurately reflect Professor Meltzer's true position in the broader debate about labor law reform, a debate which, as I noted earlier, has three dimensions-empirical, evaluative, and strategic. Our exchange here has focused on only one aspect of that initial factual component-the extent of and trends in employer reprisals against union supporters during the representation contest. However, I shall syn-

\footnotetext{
${ }^{45}$ See Theodore J. St. Antoine, Integrity and Circumspection: The Labor Law Vision of Bernard D. Meltzer, 53 U Chi L Rev 78, 112 (1986).

${ }^{46}$ I had previously written extensively about the reform of labor law in Canada. See Paul Weiler, Reconcilable Differences: New Directions in Canadian Labour Law (Carswell, 1980).
} 
opsize my own position on these broader dimensions and challenge Professor Meltzer to affirmatively state his own views.

As to the empirical question, I believe that there is now much more resistance by American businesses to a union presence in their operations than there was in the ' $50 \mathrm{~s}$. Moreover, in pursuit of the goal of a union-free workplace, far too many private sector employers (though still a minority) are prepared to fire or otherwise retaliate against union supporters in contravention of the NLRA. The result is that American workers feel serious qualms about exercising their statutory right to union representation (inhibitions that are tapped and reinforced by the tendency of almost all employers caught up in a representation campaign to paint a bleak picture of what will happen to employees if a union presence is established in the firm). Does Professor Meltzer agree or disagree with me that employees who openly espouse and seek to exercise this right, established by federal law more than fifty years ago, actually face (and believe that they face) a real threat to their future career prospects with a firm against whom they are apparently being so "disloyal"?

Even those who might accept this empirical implication of the unfair labor practice data depicted in our exchange need not endorse the further value judgment that such employer behavior and employee inhibitions should be considered unacceptable as a matter of public policy. For reasons elaborated at length in Governing the Workplace, I believe some form of union representation and free collective bargaining are essential ingredients of an acceptable market economy and political democracy. I recognize, though, that this is a contestable viewpoint; Richard Epstein, for example, has made a powerful argument to the contrary. ${ }^{47}$ Which of us does Professor Meltzer find closer to his mark?

If Professor Meltzer agrees with me that we have a "problem" in both the empirical and evaluative senses of that term, that brings us to the lawyer's task of devising new strategies through which our labor law regime might deal more effectively with the problem. My own view is that we need a lot less labor law than we have now, but that any general retrenchment on NLRB regulation should be designed to permit a more effective attack on the core problem depicted here: too many employees are losing their jobs (and consequently other employees must worry about losing their jobs) when they try to exercise their statutory right to a collective

47 See Richard A. Epstein, Common Law for Labor Relations: A Critique of the New Deal Labor Legislation, 92 Yale L J 1357 (1983). 
voice in the affairs of their workplace. In Governing the Workplace I present my program for tackling that problem. Here I am sure there are some sharp differences of view between Professor Meltzer and myself. I suspect, however, that exchanges between us on this score will be more useful and more illuminating than this debate about whether 5 percent or "just" 3 percent of union voters are being fired by their employers during the representation contest. ${ }^{48}$

48 As I stated in note 6, to keep this reply to manageable length, I have focused only on the issue of discriminatory discharge. I realize that my silence might be taken as full acquiescence with LaLonde and Meltzer's statistical observations about $\S 8(a)(5)$ and the negotiation of the first contract. I remain persuaded that employers increasingly resist a union presence in their operations through their stance at the bargaining table as well as in the election campaign. The ample anecdotal and impressionistic evidence of this phenomenon is admittedly much harder to document from the Board's spiralling § 8(a)(5) caseload. Section $8(\mathrm{a})(5)$ is both too broad (it is used more and more often in established bargaining relationships) and too narrow (it excludes the strategy of "hard" bargaining leading to a strike and permanent replacement of the union supporters).

Again, however, the bottom-line position of LaLonde and Meltzer is hard to fathom behind their statistical prestidigitation. Do they believe there is a "problem?" Is the problem worse than it was, say, thirty years ago? Are there any changes in the law they would favor to ameliorate this problem? Parenthetically, as my later writings indicate, see Governing the Workplace at 249-51 (cited in note 2), I no longer favor first contract arbitration as a remedy for bad faith bargaining. While this is a legitimate remedy in principle, it would not be effective within NLRB procedures. Instead, I favor strengthening employees' ability to help themselves through strike action: in particular, by overturning the ill-advised Supreme Court dictum in NLRB v Mackay Radio and Telegraph Co., 304 US 333, 345-46 (1938), which drew a spurious and unfair distinction between prohibited discharge and permitted permanent replacement of strikers. See Striking a New Balance, 98 Harv L Rev at 387-94 (cited in note 2); Governing the Workplace at 261-69 (cited in note 2). The significance of this issue within the NLRB's caseload radiates through Hard Times for Unions. Legislation is pending now before Congress to overturn Mackay. See S 55, 102d Cong, 1st Sess (Jan 14, 1991). 